\title{
Establishment and characterization of a mouse tumor cell line with irreversible downregulation of MHC class I molecules
}

\author{
KAROLINA LHOTAKOVA $^{1,2}$, ADRIANNA GRZELAK ${ }^{2}$, INGRID POLAKOVA ${ }^{2}$, \\ JULIE VACKOVA $^{1,2}$ and MICHAL SMAHEL ${ }^{2}$ \\ Departments of ${ }^{1}$ Cell Biology and ${ }^{2}$ Genetics and Microbiology, Faculty of Science, \\ Charles University, BIOCEV, 25250 Vestec, Czech Republic
}

Received March 29, 2019; Accepted August 23, 2019

DOI: 10.3892/or.2019.7356

\begin{abstract}
In the majority of human tumors, downregulation of major histocompatibility complex class I (MHC-I) expression contributes to the escape from the host immune system and resistance to immunotherapy. Relevant animal models are therefore needed to enhance the efficacy of cancer immunotherapy. As loss of $\beta-2$ microglobulin expression results in irreversible downregulation of surface MHC-I molecules in various human tumors, the $\beta-2$ microglobulin gene $(B 2 m)$ was deactivated in a mouse oncogenic TC-1 cell line and a TC-1/dB2m cell line that was negative for surface MHC-I expression was derived. Following stimulation with interferon $\gamma$, MHC-I heavy chains, particularly the $\mathrm{H}-2 \mathrm{D}^{\mathrm{b}}$ molecules, were found to be expressed at low levels on the cell surface, but without $\beta-2$ microglobulin. $B 2 m$ deactivation in TC-1/dB2m cells led to reduced proliferation and tumor growth. These cells were insensitive to DNA vaccination and only weakly responsive to combined immunotherapy with a DNA vaccine and the ODN1826 adjuvant. In vivo depletion demonstrated that NK1.1 $1^{+}$cells were involved in both reduced tumor growth and an antitumor effect of immunotherapy. The number of immune cells infiltrating TC- $1 / \mathrm{dB} 2 \mathrm{~m}$-induced tumors was comparable with that in tumors developing from TC-1/A9 cells characterized by reversible MHC-I downregulation. However, the composition of the cell infiltrate was different and, most importantly, infiltration with immune cells was not increased in TC-1/dB2m tumors after immunotherapy. Therefore, the TC-1/dB2m cell line represents a clinically relevant tumor model that may be used for enhancement of cancer immunotherapy.
\end{abstract}

Correspondence to: Dr Michal Smahel, Department of Genetics and Microbiology, Faculty of Science, Charles University, BIOCEV, Prumyslova 595, 25250 Vestec, Czech Republic

E-mail: smahelm@natur.cuni.cz

Key words: major histocompatibility complex class I, cancer immunotherapy, $\beta-2$ microglobulin, tumor microenvironment, DNA vaccination, $\mathrm{CpG}$ ODN

\section{Introduction}

During tumor development, oncogenic cells are under the surveillance of the host immune system. This leads to the selection of cells with adaptations that confer a survival advantage (1). The reduced expression of surface major histocompatibility complex class I (MHC-I) molecules is one of the most frequent mechanisms of evasion from immune reactions in different human tumors, ranging from $15 \%$ in renal carcinoma to $93 \%$ in lung cancer and $>75 \%$ in most types of epithelial-derived tumors (2). The majority of MHC-I aberrations are reversible and are often associated with defects in the antigen-processing machinery (APM). In that case, reduced MHC-I expression is usually caused by epigenetic silencing of the genes coding for MHC-I heavy chains or APM components (3) and may be restored by cytokines [e.g., interferon (IFN)- $\gamma$ or tumor-necrosis factor (TNF)- $\alpha$ ]. Mutations or chromosomal aberrations that affect genes encoding MHC-I heavy chains, $\beta-2$ microglobulin, proteins regulating MHC-I expression, or APM components, are responsible for the irreversible changes in surface MHC-I expression detected in approximately one-third of human tumors (4). An analysis of genomic datasets generated from thousands of solid tumors including samples of 18 tumor types revealed an association of immune cytolytic activity based on granzyme $\mathrm{A}$ and perforin expression with mutations in the invariant MHC-I chain ( $\beta-2$ microglobulin) and MHC-I (HLA) loci (5), further confirming that reduced production of MHC-I molecules is an important mechanism of tumor immune evasion. However, despite the frequency and clinical importance of MHC-I downregulation, overcoming this escape mechanism by cancer immunotherapy has not been sufficiently investigated.

The efficacy of cancer immunotherapy may be enhanced by a combination of different immunotherapeutic approaches that include activation of both adaptive and innate immunity and inhibition of immunosuppressive mechanisms $(6,7)$. Such combinations have achieved a notable antitumor effect in preclinical models $(8,9)$. However, although some mechanisms contributing to the antitumor effect are MHC-I-independent, the association of MHC-I expression on tumor cells with treatment efficacy has not been investigated. In our previous study, we examined combined immunotherapy of tumors induced in mice by the TC-1/A9 cells characterized by reversible MHC-I 
downregulation (10), and found that the combination of DNA immunization with either $\alpha$-galactosylceramide (GalCer) or the synthetic oligodeoxynucleotide ODN1826, carrying immunostimulatory $\mathrm{CpG}$ motifs, induced temporary tumor regression. $\mathrm{CD}^{+} \mathrm{T}$ cells, IFN- $\gamma$, and NK1.1 ${ }^{+}$cells were involved in this response. For ODN1826, antitumor activity of M1-polarized macrophages was also suggested.

In the present study, TC- $1 / \mathrm{dB} 2 \mathrm{~m}$ cells with a deactivated $\beta$-2 microglobulin gene $(B 2 m)$ were developed as a model of tumor cells with irreversible MHC-I downregulation in order to examine tumor growth, immune cell infiltration and sensitivity to immunotherapy by DNA vaccination combined with ODN1826 injection.

\section{Materials and methods}

Animals. A total of 250 female C57BL/6NCrl mice (7-8-weeks-old and weighing 17-22 g) were obtained from Charles River Laboratories to be used in animal experiments after at least 2 weeks of acclimatization. The mice were housed $(n=5$ per cage) and maintained under specific pathogen-free conditions and a 12/12-h light/dark cycle in a temperature-controlled room $\left(20-24^{\circ} \mathrm{C}\right)$ with a relative humidity of $50-60 \%$. The animals had access to food and water ad libitum. All animal handling procedures complied to the guidelines for the proper treatment of laboratory animals at the Czech Center for Phenogenomics (BIOCEV).

Cell lines. TC-1 tumor cells (Cellosaurus ID: CVCL_4699; kindly provided by T.-C. Wu, Johns Hopkins University) were prepared by transformation of C57BL/6 mouse primary lung cells with human papillomavirus (HPV) 16 E6/E7 oncogenes and activated $H$-ras (11). TC-1/A9 cells with reversibly downregulated MHC-I expression were derived from TC-1 cells as described previously (12). The cells were grown in high-glucose Dulbecco's modified Eagle's medium (DMEM; Sigma-Aldrich; Merck KGaA) supplemented with $10 \%$ fetal bovine serum (Biosera), $2 \mathrm{mM}$ L-glutamine, $100 \mathrm{U} / \mathrm{ml}$ penicillin and $100 \mu \mathrm{g} / \mathrm{ml}$ streptomycin.

Plasmids. The pBSC (13) and pBSC/PADRE.E7GGG (14) plasmids were used in immunization experiments. The pBSC/PADRE.E7GGG plasmid contains the HPV16 E7 oncogene with three point mutations in the pRb-binding site (E7GGG) (13) and the helper Pan HLA-DR reactive epitope (PADRE) designed in silico (15).

Deactivation of $B 2 m$ with the CRISPR/Cas9 system. The deactivation of the $B 2 m$ gene was performed with the GeneArt CRISPR Nuclease Vector Kit (Thermo Fisher Scientific, Inc.). The target site 5'-CCGAGCCCAAGACCGTCTAC-3' located in exon 2 was designed using an online software (http://crispr.mit.edu/) and cloned into the CRISPR nuclease vector as the corresponding annealed oligonucleotides synthetized by Integrated DNA Technologies. The resultant plasmid was multiplied in Escherichia coli XL-1 Blue cells, isolated by the NucleoSpin Plasmid Kit (Macherey-Nagel), and verified by sequencing with the BigDye Terminator v3.1 Cycle Sequencing Kit (Applied Biosystems; Thermo Fisher Scientific, Inc.). This plasmid was transfected into
TC-1 cells by Lipofectamine 2000 (Invitrogen; Thermo Fisher Scientific, Inc.). The cells carrying the transfected vector were selected by magnetic beads (Dynabeads FlowComp Human CD4; Thermo Fisher Scientific, Inc.) based on the human CD4 reporter gene encoded by the vector. Clones were prepared from isolated cells and analyzed by flow cytometry for MHC-I and $\beta-2$ microglobulin surface expression. The resultant clone with the deactivated $B 2 m$ gene was designated as TC $-1 / \mathrm{dB} 2 \mathrm{~m}$.

Treatment with IFN- $\gamma$. Cells were stimulated with $200 \mathrm{U} / \mathrm{ml}$ mouse recombinant IFN- $\gamma$ (PeproTech, Inc.) for $48 \mathrm{~h}$.

Flow cytometry. Cells grown in tissue culture were harvested with trypsin, washed with PBS, and stained with the following monoclonal antibodies diluted in FACS buffer ( $2 \%$ fetal bovine serum and $0.03 \%$ sodium azide in PBS) at $4{ }^{\circ} \mathrm{C}$ for $30 \mathrm{~min}$ : FITC-labeled mouse anti-B2m (clone S19.8; 1:100 dilution; Santa Cruz Biotechnology, Inc.), FITC-labeled mouse anti-mouse H-2K $\mathrm{K}^{\mathrm{b}}$ (clone CTKb; 1:200 dilution; BD Pharmingen; BD Biosciences), FITC-labeled mouse anti-mouse $\mathrm{H}-2 \mathrm{D}^{\mathrm{b}}$ (clone 28-14-8; 1:400 dilution; BD Pharmingen; BD Biosciences), or PE-labeled rat anti-mouse CD1d (clone 1B1; 1:100 dilution; BD Pharmingen; BD Biosciences). Subsequently, the cells were washed twice and measured on an LSRFortessa flow cytometer (BD Biosciences). The results were analyzed using FlowJo software v10.5.3 (BD Biosciences).

For analysis of tumor-infiltrating cells, single-cell suspensions were prepared from tumors with a longest diameter of 5-10 $\mathrm{mm}$ by using the gentleMACS Octo Dissociator (Miltenyi Biotec, $\mathrm{GmbH}$ ), as described previously (16). The obtained cells were stained with two panels of fluorescence-labeled antibodies (Table I) to identify several subpopulations of lymphoid and myeloid cells (gating strategy in Figs. S1 and S2, respectively). Viability staining was performed with Fixable Viability Dye eFluor 455UV (eBioscience; Thermo Fisher Scientific, Inc.) in PBS, prior to surface staining. To detect the nuclear Foxp3 transcription factor, the cells were treated with Fixation/Permeabilization Concentrate (eBioscience; Thermo Fisher Scientific, Inc.) diluted 1:3 with Fixation/Permeabilization Diluent (eBioscience; Thermo Fisher Scientific, Inc.). Fixation and permeabilization were followed by a washing step with permeabilization buffer (eBioscience; Thermo Fisher Scientific, Inc.) and Foxp3 staining.

In vitro cell proliferation assay. Approximately half a million live cells were seeded into three $10-\mathrm{cm}$ dishes. The cells were counted after 24,48 or $72 \mathrm{~h}$ (one dish at each interval) using a hemocytometer. Proliferation was evaluated by non-linear regression for exponential growth. Calculations were performed using Prism 8 software (GraphPad Software, Inc.).

Preparation of gene gun cartridges. Plasmid DNA was coated onto $1-\mu \mathrm{m}$ gold particles (Bio-Rad Laboratories. Inc.) according to the manufacturer's recommendations. Each cartridge contained $1 \mu \mathrm{g}$ DNA coated onto $0.5 \mathrm{mg}$ of gold particles (13).

Oncogenicity of TC-1/dB2m cells. Counts of $3 \times 10^{4}, 1 \times 10^{5}$ or $3 \times 10^{5} \mathrm{TC}-1 / \mathrm{dB} 2 \mathrm{~m}$ cells suspended in $0.15 \mathrm{ml}$ PBS were subcutaneously (s.c.) inoculated into the backs of mice $(n=5$ per 
Table I. Antibodies used for flow cytometry.

\begin{tabular}{|c|c|c|c|c|c|c|}
\hline Antigen & Conjugate & Clone & Source & Staining & & Panels \\
\hline CD11b & BV421 & $\mathrm{M} 1 / 70$ & BioLegend & Surface & & \\
\hline CD11c & APC-Cy7 & N418 & BioLegend & Surface & & \\
\hline CD25 & APC & PC61.5 & eBiosciences & Surface & $\mathrm{a}$ & \\
\hline CD3 & APC-Cy7 & $145-2 \mathrm{C} 11$ & BioLegend & Surface & $a$ & \\
\hline CD317 & APC & 927 & BioLegend & Surface & & \\
\hline CD4 & BV510 & RM4-5 & BioLegend & Surface & a & \\
\hline CD45 & Alexa Fluor 700 & 30-F11 & BioLegend & Surface & a & \\
\hline CD8 & FITC & $53-6.7$ & BD Pharmingen & Surface & $\mathrm{a}$ & \\
\hline $\mathrm{F} 4 / 80$ & BV510 & BM8 & BioLegend & Surface & & \\
\hline Foxp3 & PE & FJK-16s & eBiosciences & Nuclear & a & \\
\hline Ly6C & BV786 & HK 1.4 & BioLegend & Surface & & \\
\hline Ly6G & FITC & $1 \mathrm{~A} 8$ & BioLegend & Surface & & \\
\hline MHC-II & PE-Cy7 & 114.15 .2 & BioLegend & Surface & & \\
\hline NK1.1 & BV650 & PK136 & BioLegend & Surface & $\mathrm{a}$ & \\
\hline PD-1 & $\mathrm{PE}-\mathrm{Cy} 7 / \mathrm{PE}^{\mathrm{b}}$ & 29F.1A12 & BioLegend & Surface & a & \\
\hline PD-L1 & BV650 & 10F.9G2 & BioLegend & Surface & & \\
\hline $\operatorname{TCR} \gamma / \delta$ & BV605 & GL3 & BioLegend & Surface & $\mathrm{a}$ & \\
\hline
\end{tabular}

a,b , Antibody present in a panel.

group) under anesthesia with ketamine $(100 \mathrm{mg} / \mathrm{kg})$ and xylazine $(16 \mathrm{mg} / \mathrm{kg})$. Tumor growth was measured three times per week, and tumor size was calculated using the formula (height $\mathrm{x}$ length $\mathrm{x}$ width) $\pi / 6$. To determine the effect of $B 2 m$ deactivation on the metastatic capacity of the TC-1-derived cells, the mice were s.c. injected with $3 \times 10^{5} \mathrm{TC}-1 / \mathrm{dB} 2 \mathrm{~m}$ cells. When the size of the tumors reached $2 \mathrm{~cm}$ in any of the measured dimensions, the mice were sacrificed by cervical dislocation and dissected. The lungs were inspected for macrometastases, stained with hematoxylin and eosin, and examined under a light microscope in the Czech Center for Phenogenomics to detect micrometastases.

Immunization experiments. The mice were immunized using a gene gun (Bio-Rad Laboratories, Inc.) three times with two shots each delivering $1 \mu \mathrm{g}$ of plasmid DNA. The DNA was applied into the shaven skin of the abdomen at a discharge pressure of 400 psi. In preventive immunization experiments, mice ( $n=5$ per group) were first immunized with the pBSC/PADRE.E7GGG plasmid at 1-week interval. The pBSC plasmid was used as a negative control. One week after the last immunization, $3 \times 10^{5} \mathrm{TC}-1$ or TC- $1 / \mathrm{dB} 2 \mathrm{~m}$ cells or $3 \times 10^{4}$ TC-1/A9 cells were s.c. inoculated into the backs of the mice. In the combined immunotherapy experiments, $3 \times 10^{5} \mathrm{TC}-1 / \mathrm{dB} 2 \mathrm{~m}$ cells were s.c. injected and DNA immunization was performed after 3, 6 and 10 days. DNA vaccination was combined with an intraperitoneal (i.p.) injection of $50 \mu \mathrm{g}$ ODN1826 (Generi Biotech) or $2 \mu \mathrm{g}$ GalCer (Abcam) diluted in $200 \mu \mathrm{l}$ PBS. These immunostimulants were injected in three or five doses, as indicated in Fig. 3. Control mice received PBS.

In vivo depletion experiments. Different subpopulations of immune cells were depleted with the following antibodies (Bio X Cell) injected i.p. in a volume of $200 \mu \mathrm{l}$ of PBS: $100 \mu \mathrm{g}$
anti-CD4 (clone GK1.5), $100 \mu \mathrm{g}$ anti-CD8 (clone 2.43), or $100 \mu \mathrm{g}$ anti-NK1.1 (clone PK136). These antibodies were applied 2 days before and after inoculation of tumor cells ( $3 \times 10^{4}$ TC -1 cells or $3 \times 10^{5} \mathrm{TC}-1 / \mathrm{dB} 2 \mathrm{~m}$ cells), and then at 3-4-day intervals for 5 weeks. Moreover, $1 \mathrm{mg}$ carrageenan IV (Sigma-Aldrich; Merck KGaA) dissolved in $200 \mu \mathrm{l} \mathrm{PBS}$ was inoculated on the same days to deplete macrophages. For neutralization of IFN- $\gamma, 300 \mu \mathrm{g}$ anti-IFN- $\gamma$ (clone P4-6A2; Bio $\mathrm{X}$ Cell) was injected 2 days prior and 5, 12, 19 and 26 days after tumor cell inoculation.

In immunotherapeutic experiments, antibodies and carrageenan were administered from the 7 th day onwards after inoculation of tumor cells.

Statistical analysis. Cell proliferation and tumor growth were evaluated by two-way analysis of variance (ANOVA) and the Sidak multiple comparisons test. Intergroup comparisons of flow cytometry data were made by one-way ANOVA and Dunnett's multiple comparisons test. Calculations were performed using GraphPad Prism 8 (GraphPad Software, Inc.), and the results were considered statistically significant at $\mathrm{P}<0.05$.

\section{Results}

In vitro characterization of the TC-1 clone with $\mathrm{B} 2 \mathrm{~m}$ gene deactivation. To abrogate MHC-I expression on TC-1 tumor cells, the $B 2 m$ gene was deactivated by the CRISPR/Cas9 system and the TC-1/dB2m cell line was derived. These cells did not express $\beta$-2 microglobulin or MHC-I heavy chains on their surface (Fig. 1A). Following stimulation with IFN- $\gamma$, $\beta-2$ microglobulin was still absent on TC-1/dB2m cells, but weak MHC-I expression was induced, particularly for $\mathrm{H}-2 \mathrm{D}^{\mathrm{b}}$ molecules. 

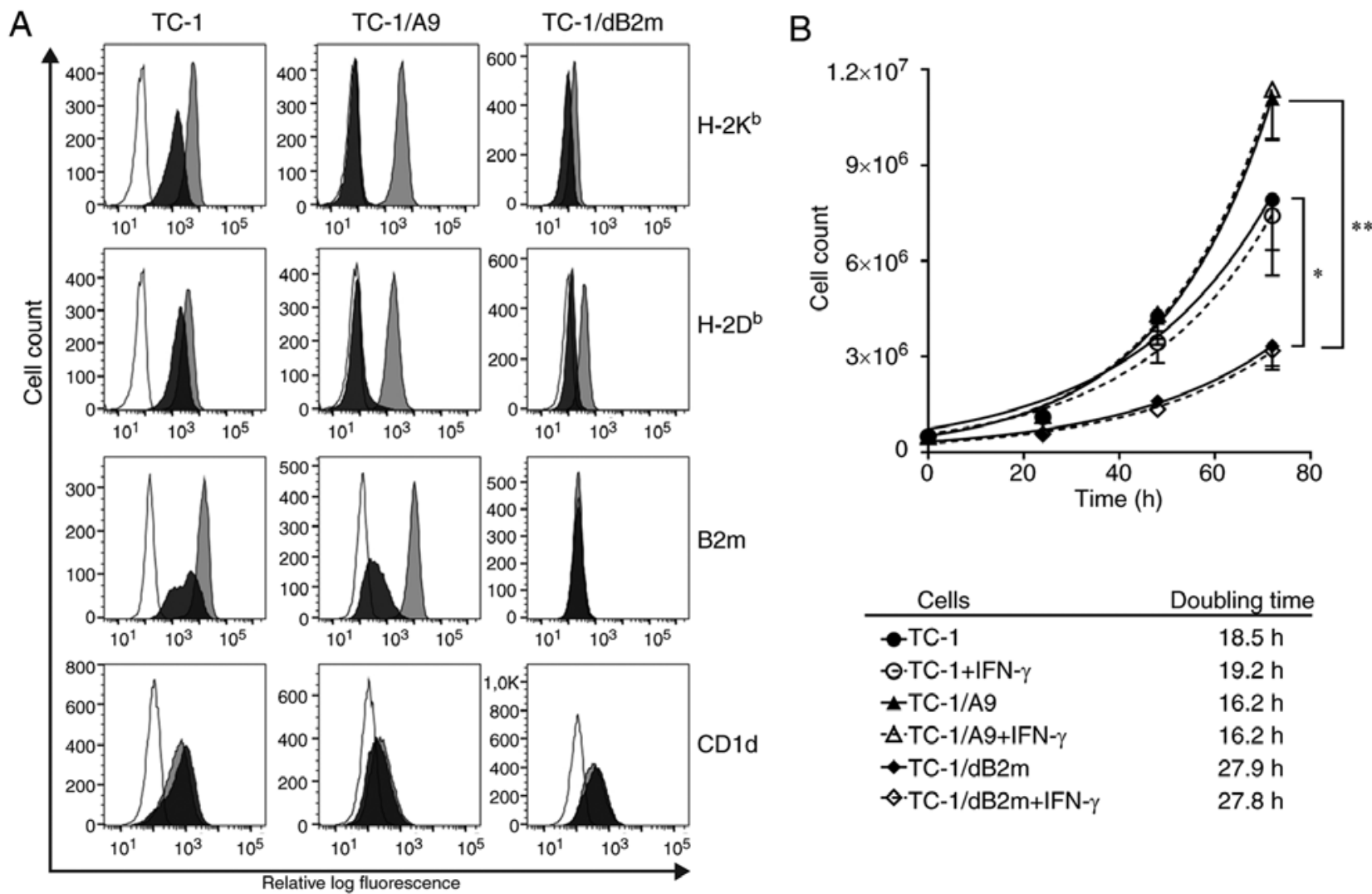

Figure 1. In vitro characterization of TC-1/dB2m cells. (A) Surface expression of $\mathrm{H}-2 \mathrm{~K}^{\mathrm{b}}, \mathrm{H}-2 \mathrm{D}^{\mathrm{b}}, \beta-2$ microglobulin (B2m) and CD1d molecules on TC-1, TC-1/A9 and TC-1/dB2m cells was analyzed by flow cytometry. Cells untreated (black histograms) or treated (grey histograms) with $200 \mathrm{U} / \mathrm{ml}$ of interferon (IFN)- $\gamma$ for $48 \mathrm{~h}$ were stained with specific monoclonal antibodies or isotype control antibodies (open histograms). (B) In vitro proliferation of TC-1, TC-1/A9 and TC-1/dB2m cells was determined at 24,48 and $72 \mathrm{~h}$ after seeding on dishes with or without IFN- $\gamma$. The results represent the mean values of three independent experiments. Bars, \pm standard error of the mean; ${ }^{*} \mathrm{P}<0.05,{ }^{* *} \mathrm{P}<0.01$.

As $\beta-2$ microglobulin also forms a complex with the CDld molecules expressed on the cell surface and CDId expression has been demonstrated on TC-1 and TC-1/A9 cells (17), CD1d expression was detected on TC-1/dB2m cells. B2m deactivation did not prevent surface expression of the CD1d molecules (Fig. 1A).

Next, the proliferation rates of TC- $1 / \mathrm{dB} 2 \mathrm{~m}, \mathrm{TC}-1$ and TC-1/A9 cells were compared. The doubling time of TC-1/dB2m cells was significantly increased by $\sim 9$ and $11 \mathrm{~h}$ in comparison with TC-1 and TC-1/A9 cells, respectively (Fig. 1B). Incubation with IFN- $\gamma$ slightly reduced TC- 1 cell proliferation, but did not affect TC-1/A9 and TC-1/dB2m cells .

In summary, deactivation of the $B 2 m$ gene in the TC- $1 / \mathrm{dB} 2 \mathrm{~m}$ cell line resulted in abrogation of $\beta-2$ microglobulin production and downregulation of surface MHC-I expression, which was associated with reduced proliferation rate.

Deactivation of the B2m gene alters oncogenicity/immunogenicity of tumor cells. To induce tumor formation, mice were inoculated s.c. with $3 \times 10^{4} \mathrm{TC}-1$ or TC-1/A9 cells. As a pilot experiment demonstrated delayed growth of tumors induced by this number of TC-1/dB2m cells, we also tested inoculation using higher numbers: $1 \times 10^{5}$ and $3 \times 10^{5} \mathrm{TC}-1 / \mathrm{dB} 2 \mathrm{~m}$ cells (Fig. 2A). However, even for the highest TC- $1 / \mathrm{dB} 2 \mathrm{~m}$ cell number $\left(3 \times 10^{5}\right)$, tumor growth was delayed by $\sim 20$ days compared with tumors induced by $3 \times 10^{4} \mathrm{TC}-1$ cells. Moreover, tumors developing from $\mathrm{TC}-1 / \mathrm{dB} 2 \mathrm{~m}$ cells were more elongated in comparison with TC-1-induced tumors, particularly at the early growth phase. Spontaneous lung metastasis formation was not observed after s.c. induced tumors.

To identify the immune cells that could inhibit the growth of TC- $1 / \mathrm{dB} 2 \mathrm{~m}$-induced tumors, some subpopulations were depleted in vivo by monoclonal antibodies (Fig. 2B). For TC-1-induced tumors, $\mathrm{CD}^{+}$and $\mathrm{NK} 1.1^{+}$cells were found to contribute to the reduction of tumor growth, and macrophages supported this growth. NK1.1 $1^{+}$cells also inhibited TC-1/A9 and TC- $1 / \mathrm{dB} 2 \mathrm{~m}$ tumors, but there was no involvement of $\mathrm{CD} 8^{+}$ cells or macrophages. In all types of tumors, the depletion of $\mathrm{CD} 4{ }^{+}$cells or neutralization of IFN- $\gamma$ did not significantly affect tumor growth (the antitumor effect of IFN- $\gamma$ was only apparent during the initial phase of the growth of TC-1 tumors).

Next, the sensitivity of TC-1/dB2m-induced tumors to adaptive immunity activated against the HPV16 E7 oncoprotein was evaluated. While TC-1 tumors are highly sensitive to therapeutic DNA immunization by the PADRE. E7GGG vaccine (14), the sensitivity of TC-1/A9 tumors to DNA vaccination is low (10). After more efficient preventive immunization with the PADRE.E7GGG gene, the growth of TC-1/A9-induced tumors was significantly reduced, but the $\mathrm{TC}-1 / \mathrm{dB} 2 \mathrm{~m}$ tumors were resistant to DNA vaccination (Fig. 2C). The development of control TC-1 tumors was inhibited in all mice.

Collectively, these findings indicate that deactivation of the $B 2 m$ gene resulted in delayed tumor growth and resistance to adaptive immunity. 

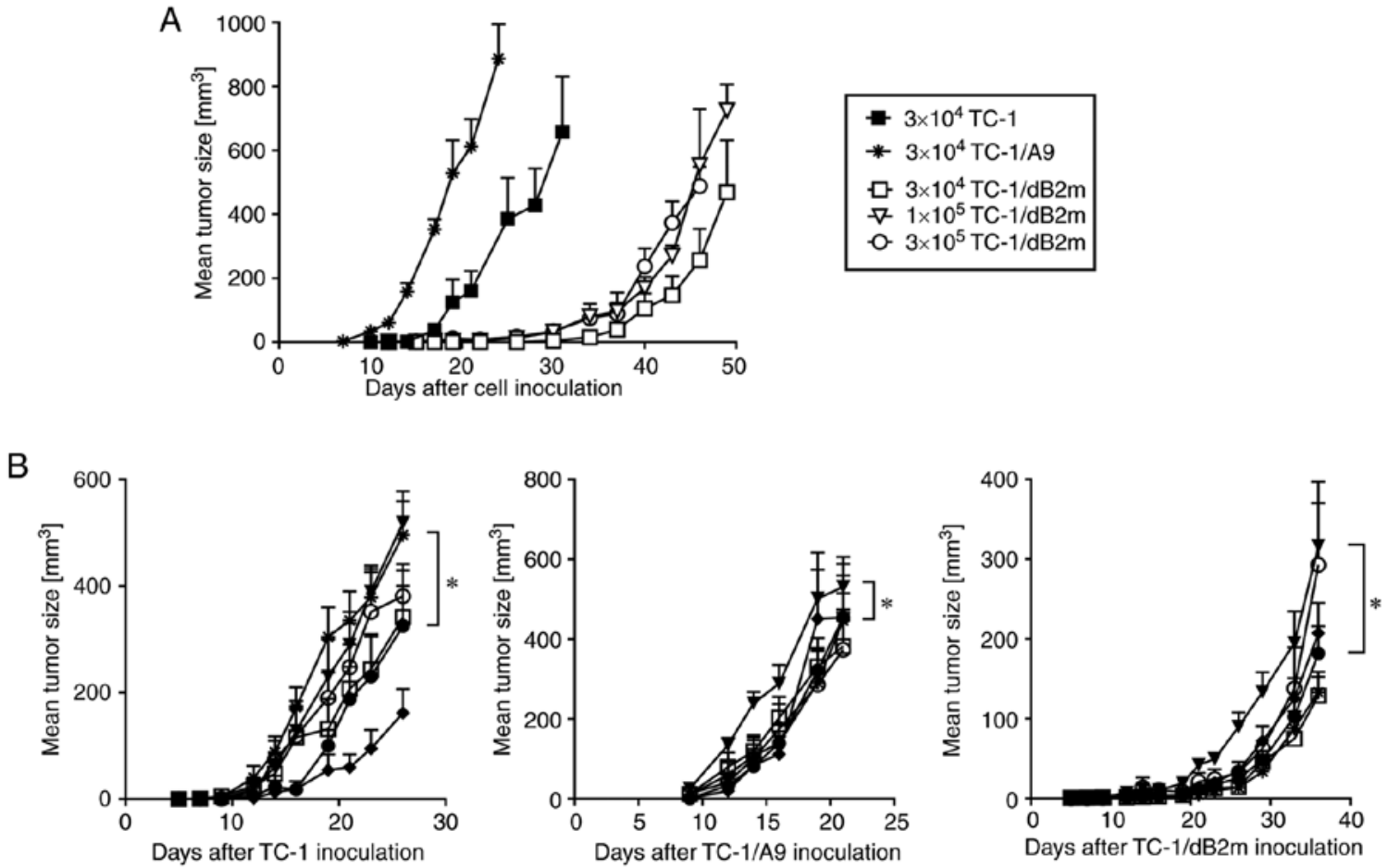

\begin{tabular}{|lll|}
\hline$\bullet$ PBS & $*$ Anti-CD8 & $\bullet$ Carrageenan \\
$\bullet$ Anti-CD4 & $\leftarrow$ Anti-NK1.1 & $\bullet$ anti-IFN- $\gamma$ \\
\hline
\end{tabular}
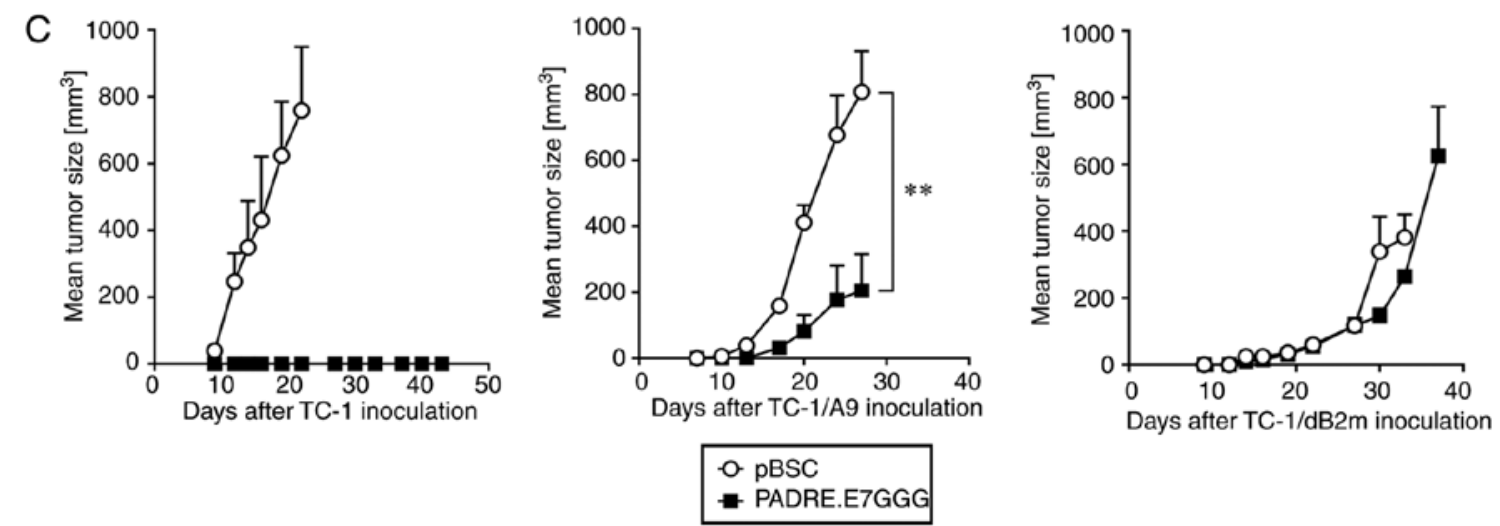

Figure 2. In vivo characterization of TC-1/dB2m cells. (A) Tumor growth in mice ( $\mathrm{n}=5$ ) was evaluated after s.c. inoculation. (B) Immune cells involved in inhibition of tumor growth were analyzed by in vivo depletion with anti-CD4, anti-CD8 and anti-NK1.1 antibodies and carrageenan IV. The effect of interferon (IFN)- $\gamma$ was examined by neutralization with anti-IFN- $\gamma$. PBS was used as control. (C) Sensitivity to DNA immunization was tested in mice preimmunized three times with the PADRE.E7GGG vaccine. Empty pBSC plasmid and parental TC-1 cells were used as controls. Tumor growth was measured three times per week. Bars, \pm standard error of the mean; ${ }^{*} \mathrm{P}<0.05,{ }^{* *} \mathrm{P}<0.01$.

TC-1/dB2m cells are slightly sensitive to combined immunotherapy. As combinations of DNA vaccination with i.p. injection of ODN1826 or GalCer reduced tumor growth of TC-1/A9 cells (10), these immunotherapies were also examined against TC-1/dB2m cells. However, only a weak antitumor effect was observed (Fig. 3A). Due to the delayed growth of $\mathrm{TC}-1 / \mathrm{dB} 2 \mathrm{~m}$ tumor, and in an attempt to enhance antitumor immunity, the interval between the injections of immunostimulatory drugs was prolonged and the number of ODN1826 doses was increased from three to five. Although these modifications only exerted a weak effect, a significant reduction of tumor growth was achieved by ODN1826 combined with DNA immunization (Fig. 3B). This experiment also demonstrated that a combination of DNA vaccination with ODN1826 or
GalCer was necessary for the antitumor response, as either therapy alone did not result in tumor reduction. Thus, repeated experiments suggested a weak inhibition of tumor development following combined immunotherapy, and this effect was more obvious for ODN1826.

NK1.1 cells mainly contribute to the antitumor effect of combined immunotherapy. In order to identify the immune cells involved in the antitumor response to combined therapy against TC-1/dB2m tumors, tumor-infiltrating cells were first analyzed by flow cytometry using two panels of monoclonal antibodies. In this experiment, tumor-infiltrating cells in TC-1- and TC-1/A9-induced tumors were also compared. The numbers of $\mathrm{CD} 45^{+}$cells in the tumors were comparable for 
A
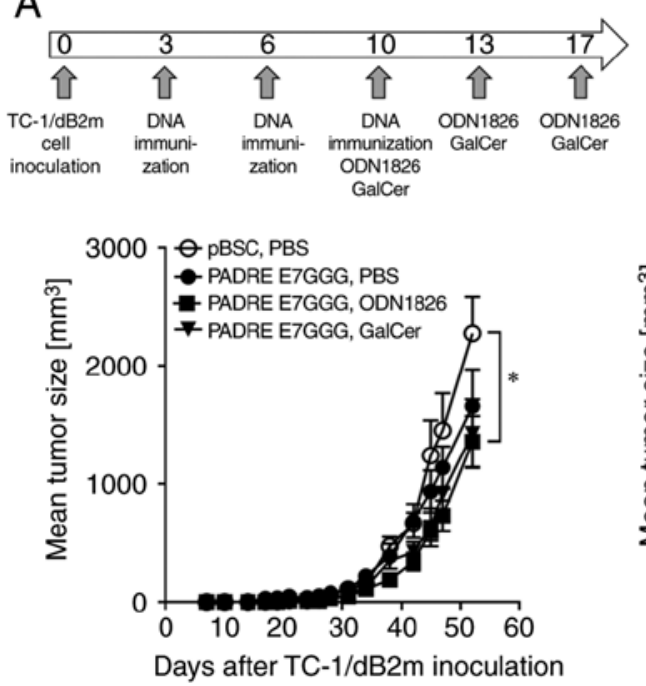

B
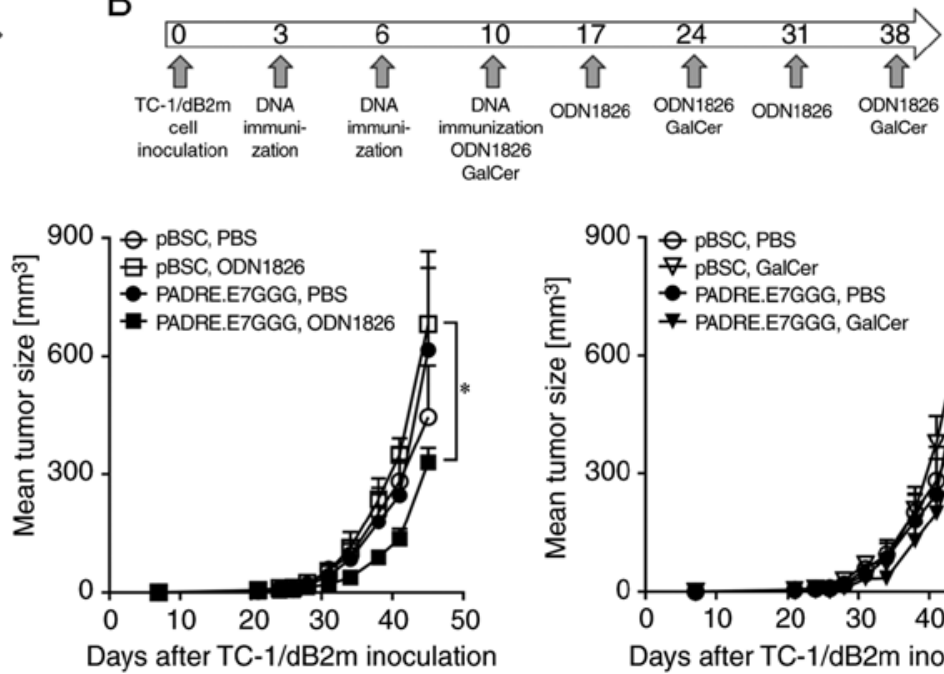

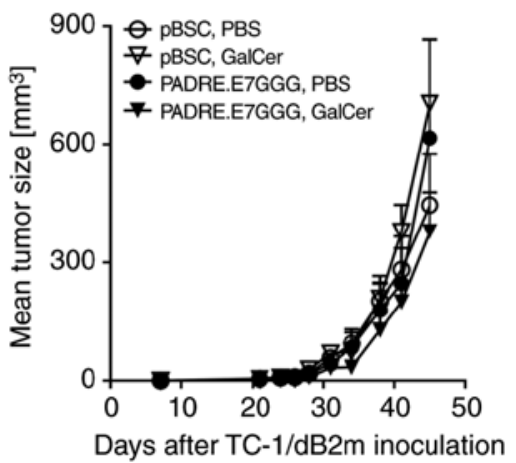

Figure 3. Antitumor effect of DNA vaccination combined with either ODN1826 or GalCer. Adjuvants were administered 10-17 days (A) or 10-38 days (B) after inoculation of tumor cells. pBSC and PBS were used as controls. Tumor growth was measured three times a week. Bars, \pm standard error of the mean; ${ }^{*}<0.05$.

all three cell lines examined, and did not change after therapy of $\mathrm{TC}-1 / \mathrm{dB} 2 \mathrm{~m}$-induced tumors. In tumors that developed from $\mathrm{TC}-1 / \mathrm{dB} 2 \mathrm{~m}$ cells, $\mathrm{CD} 3^{+}$cells comprised a significantly higher proportion of $\mathrm{CD} 45^{+}$cells $(\sim 11 \%)$ that was not altered following immunotherapy (Fig. 4A).

Among lymphoid cells (Fig. 4B), NK cells (CD3-NK1.1 ${ }^{+}$) were predominant in all types of tumors, but their proportion was significantly lower in TC-1/dB2m compared with that in TC-1/A9 tumors (accounting for 13 and $30 \%$ of CD $45^{+}$cells, respectively). On the contrary, the proportion of $\mathrm{CD}^{+} \mathrm{T}$ cells and $\gamma \delta \mathrm{T}$ cells was significantly higher in TC-1/dB2m tumors compared with those in TC-1/A9 and TC-1 tumors. Regulatory T cells (Treg; CD $4^{+} \mathrm{CD} 25^{+} \mathrm{Foxp} 3^{+}$) were partially responsible for the increase in $\mathrm{CD}^{+} \mathrm{T}$ cells. The numbers of NKT cells $\left(\mathrm{CD} 3^{+} \mathrm{TCR} \gamma / \delta^{-} \mathrm{NK} 1.1^{+}\right)$were also higher in TC-1/dB2m tumors, but this difference was not significant. After immunotherapy of TC-1/dB2m tumors, the proportion of any lymphoid subpopulation was not significantly altered. Significantly enhanced PD-1 expression was only observed on NK and NKT cells.

Tumor-associated macrophages (TAMs; CD11b ${ }^{+} \mathrm{Ly}_{6 \mathrm{G}^{-}}$ Ly6C-F4/80+) comprised a major subpopulation of myeloid cells in all types of tumors (Fig. 4C). In TC-1/dB2m tumors, their numbers were significantly lower compared with those in TC-1 and TC-1/A9 tumors, but they expressed a higher level of MHC-II molecules that are considered a marker of M1-polarized macrophages $(18,19)$. Following immunotherapy of TC-1/dB2m tumors, the numbers of macrophages and their PD-1 expression were slightly enhanced. In TC-1/dB2m tumors generated in non-treated mice, the populations of dendritic cells, both conventional (cDC; CD11 ${ }^{+} \mathrm{Ly}_{6 \mathrm{G}}{ }^{-} \mathrm{Ly} 6 \mathrm{C}^{-} \mathrm{F} 4 / 80^{-} \mathrm{MHC}-\mathrm{II}^{+}$) and plasmacytoid (pDC; CD11 ${ }^{+} \mathrm{CD} 11 \mathrm{~b}^{-} \mathrm{Ly}_{6 \mathrm{G}}{ }^{-} \mathrm{Ly}^{-} \mathrm{C}^{+} \mathrm{F} 4 / 80^{-}$ $\mathrm{MHC}-\mathrm{II}^{+} \mathrm{CD} 317^{+}$), were significantly higher compared with those in TC-1 and TC-1/A9 tumors and were not altered after immunotherapy. The numbers of myeloid-derived suppressor

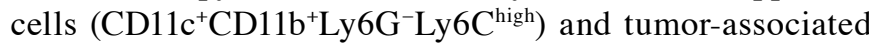
neutrophils $\left(\mathrm{CD} 11 \mathrm{~b}^{+}\right.$Ly6 $\left.\mathrm{G}^{\text {high }} \mathrm{Ly} 6 \mathrm{C}^{\text {low }}\right)$ were comparable in all types of tumors.
Next, we examined cells involved in antitumor immunity by in vivo depletion. In mice treated with immunotherapy (DNA vaccination plus injection of ODN1826), tumor growth was significantly enhanced only after elimination of NK1.1 ${ }^{+}$ cells (Fig. 4D). Neutralization of IFN- $\gamma$ suggested that this cytokine played a crucial role in the antitumor effect. After depletion of $\mathrm{CD}^{+}$cells, tumor growth was comparable to that in mice treated with anti-NK $1.1^{+}$until day 27 after inoculation of tumor cells. Subsequently, the growth of tumors was similarly reduced in animals with depleted $\mathrm{CD} 8^{+}$cells and administered immunotherapy alone.

In summary, combined immunotherapy of TC-1/dB2m-induced tumors did not result in significantly increased immune cell infiltration. NK1.1 $1^{+}$cells and IFN- $\gamma$ contributed to the weak antitumor effect. Enhanced expression of the PD-1 receptor on NK and NKT cells suggests that both types of cells may be involved in this effect.

\section{Discussion}

The production of $\beta-2$ microglobulin is often abrogated by genetic alterations in human tumors (20). As these modifications lead to irreversible downregulation of surface MHC-I expression that is associated with resistance to $\mathrm{CD} 8^{+}$cytotoxic $\mathrm{T}$ lymphocytes (CTLs), they enable evasion of adaptive immune responses generated during tumor development or induced by immunotherapy. Such resistance has also been demonstrated for a blockade of the PD-1 immune checkpoint by a monoclonal antibody (21). Therefore, the development of relevant tumor models is necessary for studies of experimental cancer immunotherapy that may result in enhancement of clinical trial efficacy.

The CRISPR/Cas9 system has been recently used for the deactivation of the $B 2 \mathrm{~m}$ gene in two mouse tumor cell lines, namely melanoma B16F10 and breast cancer EO-771 cells (22). In the present study, the $B 2 m$ gene was deactivated in the mouse TC-1 cell line, which is often used to examine various cancer therapies. $B 2 m$ deactivation in TC- $1 / \mathrm{dB} 2 \mathrm{~m}$ 


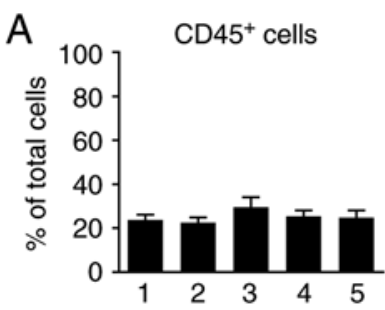

B

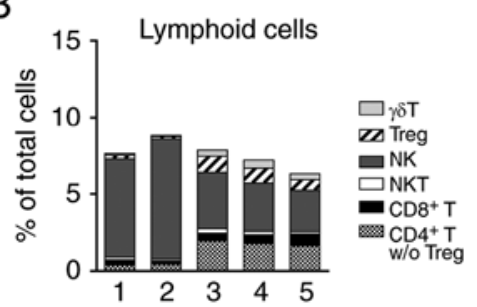

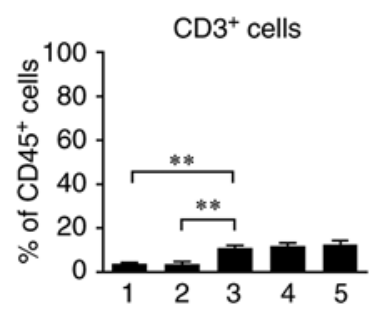

$\mathrm{CD}^{+}$cells
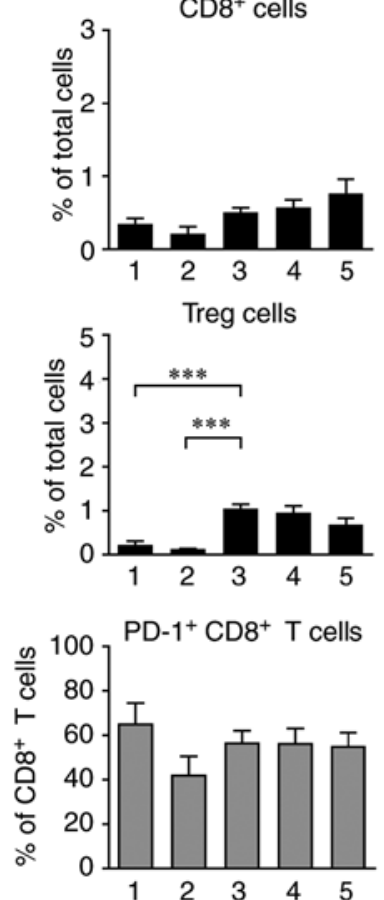

C

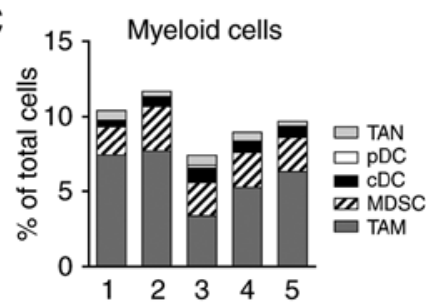

TAM-MHC-II

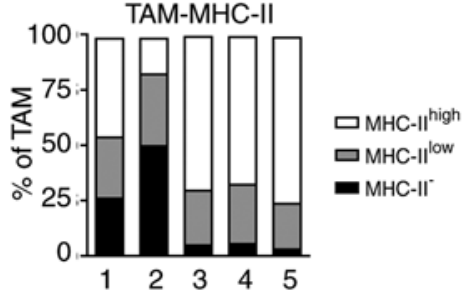

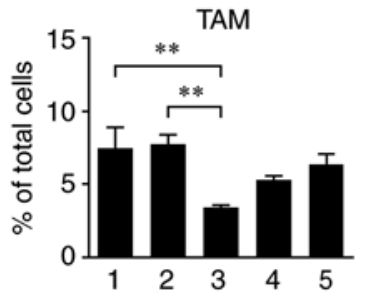

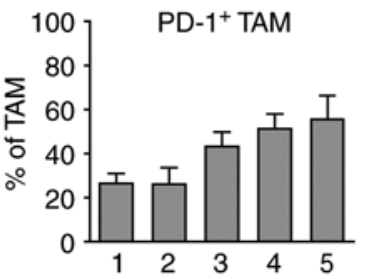

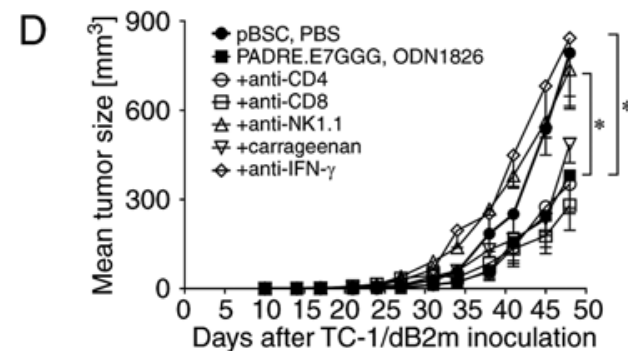

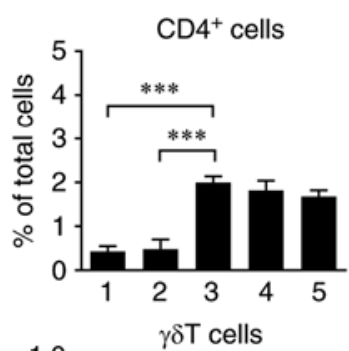

NKT cells
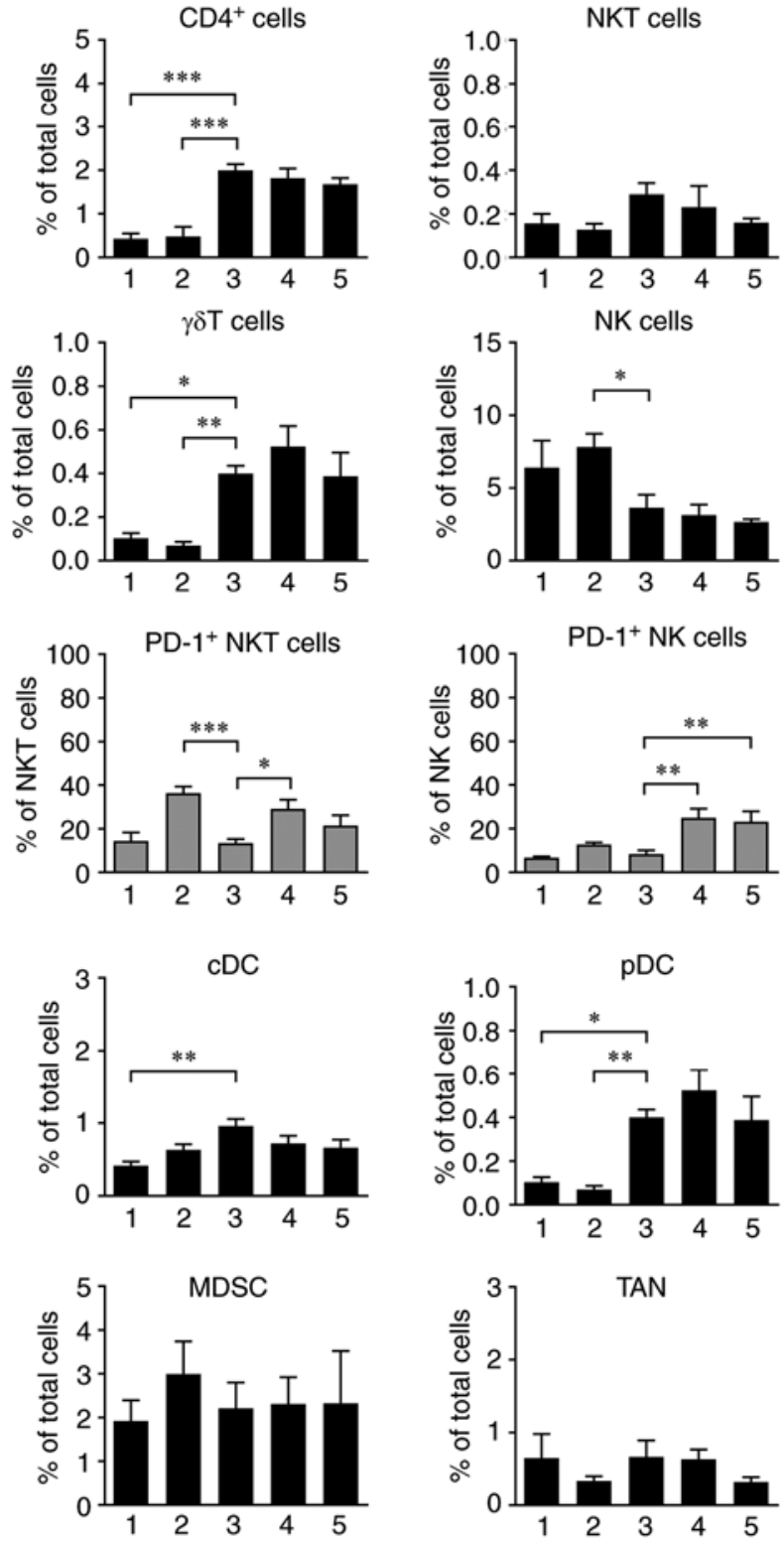

Figure 4. Immune cells contributing to the antitumor effect. (A-C) The cells infiltrating tumors induced by TC-1, TC-1/A9, or TC-1/dB2m cells were analyzed by flow cytometry. For TC-1/dB2m cells, tumors after immunotherapy with ODN1826 and DNA vaccination with PADRE.E7GGG were also examined. Using two panels of monoclonal antibodies, (B) lymphoid and (C) myeloid subpopulations were identified. (D) Infiltrating immune cells contributing to the reduction of tumor growth after combined immunotherapy with ODN1826 and PADRE.E7GGG were identified by in vivo depletion. Interferon (IFN)- $\gamma$ was also neutralized. Bars, \pm standard error of the mean; ${ }^{*} \mathrm{P}<0.05,{ }^{* *} \mathrm{P}<0.01,{ }^{* * * *} \mathrm{P}<0.001$.

cells was associated with loss of surface MHC-I expression, but when inducibility by IFN- $\gamma$ was tested, a slight restoration of MHC-I expression on the cell surface, particularly of molecules from the $\mathrm{D}$ locus, was observed. As $\beta-2$ microglobulin expression remained negative, it was hypothesized that $\beta$-2 microglobulin-free MHC-I heavy chains were displayed on the cells. Such molecules, particularly $\mathrm{H}-2 \mathrm{D}^{\mathrm{b}}$, have been reported for both $\beta-2$ microglobulin-negative and -positive mouse cells (23-25); however, the role of IFN- $\gamma$ stimulation was not described in these studies. In a human neuroblastoma cell line producing $\beta-2$ microglobulin, the expression of $\beta-2$ microglobulin-free MHC-I molecules was enhanced upon differentiation with either retinoic acid or serum starvation. Incubation with IFN- $\gamma$ increased the surface expression of 
MHC-I heterodimers, but not of $\beta$ - 2 microglobulin-free MHC-I molecules (26). In concordance with the published results (27), the present study demonstrated that $B 2 m$ deactivation did not prevent CD1d surface expression.

Deactivation of the $B 2 m$ gene significantly reduced the proliferation of $\mathrm{TC}-1 / \mathrm{dB} 2 \mathrm{~m}$ cells and the growth of TC-1/dB2m-induced tumors. These results correspond to the findings that $\beta-2$ microglobulin promotes cell proliferation, migration, and invasion in different tumor types $(28,29)$. A key role in this $\beta-2$ microglobulin-mediated signaling was attributed to its binding with hemochromatosis (HFE) protein, a non-classical MHC-I molecule that regulates iron concentration in cells. Following formation of the $\beta-2$ microglobulin/HFE complex, iron influx is inhibited and numerous intracellular pathways are affected (30).

A reduced proliferation rate may contribute to the delay in tumor growth, but does not appear to be a crucial factor responsible for the substantially decreased oncogenicity of TC- $1 / \mathrm{dB} 2 \mathrm{~m}$ cells. As in vivo depletion was associated with partial restoration of tumor growth after application of NK1.1-specific antibody, enhanced sensitivity to elimination by NK cells may be more important. Das et al (22) observed a similar reduction of oncogenicity following $B 2 m$ deactivation in two mouse tumor cell lines and also suggested a role of NK cells in this phenomenon.

The effect of MHC-I downregulation after $B 2 m$ deactivation was also manifested by the loss of sensitivity to depletion of $\mathrm{CD}^{+}$cells and to adaptive immunity induced by DNA immunization and mediated by CTLs. As similar effects were observed for TC-1/A9 cells, where a combination of DNA immunization and an adjuvant (ODN1826 or GalCer) significantly reduced tumor growth (10), the efficacy of this combined immunotherapy was also examined against TC-1/dB2m tumors. However, only the combination of DNA vaccination and ODN1826 injection significantly inhibited tumor growth, and this effect was less notable compared with that against TC-1/A9-induced tumors.

Flow cytometric analysis of tumor-infiltrating immune cells and in vivo depletion after immunotherapy revealed several marked differences between TC-1/dB2 $\mathrm{m}$ and TC-1/A9 tumors: i) TC-1/dB2m tumors contained more $\mathrm{pDCs}, \mathrm{CD} 4^{+} \mathrm{T}$, Treg, and $\gamma \delta$ T cells, but fewer TAMs and NK cells. However, this observation should be interpreted with caution, as infiltration of tumors with immune cells is a dynamic process with specific kinetics of individual subpopulations (8,31-33), which hampers a direct comparison among tumors induced by different cells. Although we strived to analyze tumors of similar size, the composition of the cell infiltrate may be affected by the markedly different growth of TC-1-, TC-1/A9- and TC-1/dB2m-induced tumors. ii) Following combined immunotherapy, none of the examined subpopulations of infiltrating immune cells was increased in the TC-1/dB2m tumors, while in the TC-1/A9 tumors, most subpopulations were increased, particularly $\mathrm{CD}^{+} \mathrm{T}$ cells (10). iii) MHC-II ${ }^{\text {high }}$ TAMs were predominant in TC-1/dB2m tumors, even without immunotherapy (while in the TC-1/A9 tumors, they were predominant only after immunotherapy). Reduced numbers of M2 TAMs were mainly responsible for this effect. Movahedi et al reported similar results for the 4T1 cell line (18). Progressing tumors induced by these cells accumulated MHC-II ${ }^{\text {high }}$ TAMs, in contrast to tumors induced by $3 \mathrm{LL}$ or TS/A cells, and these TAMs remained M1 polarized. Therefore, it was concluded that the proportions of TAM subsets were tumor-dependent. iv) For TC-1/A9 tumors, NK1.1 $1^{+}$cells, $\mathrm{CD}^{+}$cells and TAMs cooperated in the antitumor response, but only NK1.1 $1^{+}$cells were significantly implicated in the delay of TC- $1 / \mathrm{dB} 2 \mathrm{~m}$ tumor growth. Enhanced PD-1 expression on both NK and NKT cells after immunotherapy suggested activation of both cell types by treatment and their possible involvement in antitumor immunity.

By using in vivo depletion of $\mathrm{CD}^{+}, \mathrm{CD} 4^{+}$and $\mathrm{NK} 1.1^{+}$cells, studies comparing immunotherapy against TC-1 cells and TC-1 clones with reversible MHC-I downregulation demonstrated that only $\mathrm{CD} 8^{+} \mathrm{T}$ cells were necessary for the antitumor effect against TC- 1 cells, and that both $\mathrm{CD} 8^{+}$and NK1.1 $1^{+}$cells may be involved in the inhibition of tumors induced by cells with reversibly downregulated MHC-I expression $(34,35)$, which was confirmed in our previous study with TC-1/A9 cells (10). This study extended these observations for the TC-1 clone with irreversible MHC-I downregulation, demonstrating that NK1.1 $1^{+}$cells were the most important for the antitumor effect stimulated by immunotherapy against TC- $1 / \mathrm{dB} 2 \mathrm{~m}$ cells . For TC-1-induced tumors, two other studies demonstrated the cooperation of $\mathrm{CD}^{+} \mathrm{T}$ cells with other immune cells in the antitumor response after immunotherapy, but suggested that $\mathrm{CD} 8^{+} \mathrm{T}$ cells were not the main cytotoxic cells eliminating MHC-I-proficient TC-1 cells $(8,36)$. Our study with TC-1/A9 cells, which are deficient in MHC-I expression, also demonstrated a role of $\mathrm{CD} 8^{+} \mathrm{T}$ cells activated by DNA vaccination in the antitumor response (10). However, in the present study, despite the fact that DNA vaccination was necessary for the induction of the antitumor effect by combined immunotherapy, the level of $\mathrm{CD}^{+} \mathrm{T}$ cells in the tumors was not increased by treatment, and the function of $\mathrm{CD} 8^{+} \mathrm{T}$ cells was not proven by in vivo depletion. The only observation suggesting the involvement of $\mathrm{CD} 8^{+} \mathrm{T}$ cells was derived from the in vivo depletion experiment, where augmented tumor growth was recorded at the initial phase of tumor development (up to day 27) following application of anti-CD8. As tumor infiltration by immune cells is a dynamic process (8), this fact should be confirmed by further studies investigating a more efficient immunotherapy against TC- $1 / \mathrm{dB} 2 \mathrm{~m}$ cells, which may also help elucidate the role of $\mathrm{CD}^{+} \mathrm{T}$ cells and other immune cells in this tumor model.

As combined immunotherapy only weakly inhibited the growth of TC-1/dB2m tumors and did not affect infiltration of these tumors by immune cells, immunosuppressive mechanisms most likely prevail in the microenvironment of early-stage tumors. This condition resembles human MHC-I-negative tumors that are often devoid of immune cells in the tumor parenchyma and contain unfunctional immune cells in the tumor stroma $(37,38)$. Therefore, for successful immunotherapy of such tumors, activation of adaptive and innate immunity should be accompanied by appropriate inhibition of immunosuppression and recovery of MHC-I expression $(4,39,40)$.

The mechanisms of immune reactions against $\mathrm{TC}-1 / \mathrm{dB} 2 \mathrm{~m}$-induced tumors were not completely elucidated in the present study, and will be the subject of further analyses. The present results suggest that, following immunotherapy, $\mathrm{NK} 1.1^{+}$cells were the major cell type exhibiting 
antitumor activity against TC-1/dB2m tumors. The possible involvement of both NK and NKT cells was indicated by enhanced PD-1 expression, which suggested the activation and subsequent inactivation of these cells. The antitumor effect of NKT cells, which constitute a minor subpopulation of NK1.1 $1^{+}$cells, was also suggested by immunotherapy with GalCer, as this adjuvant activates NKT cells. However, NK cells are likely the main effector cells, as they can eliminate tumor cells with downregulated MHC-I expression. Unfortunately, they can also contribute to tumor immune evasion (41). The antitumor effect of ODN1826 may not be dependent on adaptive immunity (42); however, DNA immunization was necessary for the reduced growth of $\mathrm{TC}-1 / \mathrm{dB} 2 \mathrm{~m}$ tumors. The role of $\mathrm{CD}^{+} \mathrm{T}$ cells in antitumor reactions was not clearly confirmed by in vivo depletion, but this experiment indicated the effect of these cells during early tumor growth. At a later stage of tumor development, $\mathrm{CD}^{+} \mathrm{T}$ cells are likely inactivated by the immunosuppressive tumor microenvironment (43).

In conclusion, deactivation of the $B 2 m$ gene led to the creation of the TC- $1 / \mathrm{dB} 2 \mathrm{~m}$ cell line, which is characterized by irreversible MHC-I downregulation, and a reduced proliferation rate and tumor growth. These cells displayed loss of sensitivity to DNA immunization and, in comparison to the TC-1/A9 cells with reversible MHC-I downregulation, they responded more weakly to combined immunotherapy consisting of DNA vaccination and either ODN1826 or GalCer injection. Moreover, infiltration of TC-1/dB2m tumors with immune cells was not enhanced after immunotherapy, and only NK1.1 ${ }^{+}$cells were confirmed to contribute to the antitumor effect. In a set with TC-1 and TC-1/A9 cells, the TC- $1 / \mathrm{dB} 2 \mathrm{~m}$ cell line may be utilized for enhancement of cancer immunotherapy with a potentially high clinical benefit, as human tumors are heterogeneous in terms of MHC-I expression, which enables evasion of the immune response and confers resistance to therapy.

\section{Acknowledgements}

The authors would like to thank Pavlina Vesela, Kristyna Klecakova and Nela Vaclavikova for technical assistance. We also acknowledge the Imaging Methods Core Facility at BIOCEV for their support with obtaining the flow cytometry data presented in this article.

\section{Funding}

The present study was funded by the Czech Science Foundation (grant nos. GA16-04477S and GA19-00816S); the European Regional Development Fund (grant nos. CZ.02.1.01/0.0/0.0/16_019/0000785, CZ.1.05/1.1.00/02.0109, CZ.1.05/2.1.00/19.0400 and CZ.1.05/2.1.00/19.0395); the Ministry of Education, Youth and Sports of the Czech Republic (grant nos. LQ1604 and LM2015040); and Charles University (grant no. SVV-2017-260426).

\section{Availability of data and materials}

All data generated or analyzed during the present study are included in this published article.

\section{Authors' contributions}

MS conceived and designed the study. KL, AG, IP, JV and MS performed the experiments. MS, IP, KL and JV analyzed and interpreted the data. KL, MS and IP wrote the manuscript. All authors have read and approved the final version of this manuscript for publication.

\section{Ethics approval and consent to participate}

All animal experimental procedures were performed in compliance with Directive 2010/63/EU, and animal protocols were approved by the Sectoral Expert Committee of the Czech Academy of Sciences for Approval of Projects of Experiments on Animals (reference no. 46/2016, 16 May 2016).

\section{Patient consent for publication}

Not applicable.

\section{Competing interests}

The authors declare that they have no competing interests.

\section{References}

1. Khong HT and Restifo NP: Natural selection of tumor variants in the generation of 'tumor escape' phenotypes. Nat Immunol 3: 999-1005, 2002.

2. Garrido F, Ruiz-Cabello F and Aptsiauri N: Rejection versus escape: The tumor MHC dilemma. Cancer Immunol Immunother 66: 259-271, 2017.

3. Reinis M: Immunotherapy of MHC class I-deficient tumors. Future Oncol 6: 1577-1589, 2010.

4. Garrido F, Aptsiauri N, Doorduijn EM, Garcia Lora AM and van Hall T: The urgent need to recover MHC class I in cancers for effective immunotherapy. Curr Opin Immunol 39: 44-51, 2016.

5. Rooney MS, Shukla SA, Wu CJ, Getz G and Hacohen N: Molecular and genetic properties of tumors associated with local immune cytolytic activity. Cell 160: 48-61, 2015

6. Smyth MJ, Ngiow SF, Ribas A and Teng MW: Combination cancer immunotherapies tailored to the tumour microenvironment. Nat Rev Clin Oncol 13: 143-158, 2016.

7. Zappasodi R, Merghoub T and Wolchok JD: Emerging concepts for immune checkpoint blockade-based combination therapies. Cancer Cell 33: 581-598, 2018.

8. Thoreau M, Penny HL, Tan K, Regnier F, Weiss JM, Lee B, Johannes L, Dransart E, Le Bon A, Abastado JP, et al: Vaccine-induced tumor regression requires a dynamic cooperation between $\mathrm{T}$ cells and myeloid cells at the tumor site. Oncotarget 6: 27832-27846, 2015.

9. Moynihan KD, Opel CF, Szeto GL, Tzeng A, Zhu EF, Engreitz JM, Williams RT, Rakhra K, Zhang MH, Rothschilds AM, et al: Eradication of large established tumors in mice by combination immunotherapy that engages innate and adaptive immune responses. Nat Med 22: 1402-1410, 2016.

10. Grzelak A, Polakova I, Smahelova J, Vackova J, Pekarcikova L, Tachezy R and Smahel M: Experimental combined immunotherapy of tumours with major histocompatibility complex class I downregulation. Int J Mol Sci 19: E3693, 2018.

11. Lin KY, Guarnieri FG, Staveley-O'Carroll KF, Levitsky HI, August JT, Pardoll DM and Wu TC: Treatment of established tumors with a novel vaccine that enhances major histocompatibility class II presentation of tumor antigen. Cancer Res 56: 21-26, 1996.

12. Smahel M, Sima P, Ludvikova V, Marinov I, Pokorna D and Vonka V: Immunisation with modified HPV16 E7 genes against mouse oncogenic TC-1 cell sublines with downregulated expression of MHC class I molecules. Vaccine 21: 1125-1136, 2003.

13. Smahel M, Sima P, Ludvikova V and Vonka V: Modified HPV16 E7 genes as DNA vaccine against E7-containing oncogenic cells. Virology 281: 231-238, 2001. 
14. Smahel M, Polakova I, Duskova M, Ludvikova V and Kastankova I: The effect of helper epitopes and cellular localization of an antigen on the outcome of gene gun DNA immunization. Gene Ther 21: 225-232, 2014.

15. Alexander J, Sidney J, Southwood S, Ruppert J, Oseroff C, Maewal A, Snoke K, Serra HM, Kubo RT and Sette A: Development of high potency universal DR-restricted helper epitopes by modification of high affinity DR-blocking peptides. Immunity 1: 751-761, 1994.

16. Kaštánková I, Poláková I, Dušková $M$ and Šmahel M: Combined cancer immunotherapy against aurora kinase A. J Immunother 39: 160-170, 2016.

17. Simova J, Indrova M, Bieblová J, Mikyskova R, Bubeník J and Reinis M: Therapy for minimal residual tumor disease: $\beta$-galactosylceramide inhibits the growth of recurrent HPV16-associated neoplasms after surgery and chemotherapy Int J Cancer 126: 2997-3004, 2010.

18. Movahedi K, Laoui D, Gysemans C, Baeten M, Stange G, Van den Bossche J, Mack M, Pipeleers D, In't Veld P, De Baetselier P and Van Ginderachter JA: Different tumor microenvironments contain functionally distinct subsets of macrophages derived from Ly6C(high) monocytes. Cancer Res 70: 5728-5739, 2010.

19. Mills CD and Ley K: M1 and M2 macrophages: The chicken and the egg of immunity. J Innate Immun 6: 716-726, 2014.

20. Bernal M, Ruiz-Cabello F, Concha A, Paschen A and Garrido F: Implication of the $\beta 2$-microglobulin gene in the generation of tumor escape phenotypes. Cancer Immunol Immunother 61 : $1359-1371,2012$

21. Zaretsky JM, Garcia-Diaz A, Shin DS, Escuin-Ordinas H, Hugo W, Hu-Lieskovan S, Torrejon DY, Abril-Rodriguez G, Sandoval S, Barthly L, et al: Mutations associated with acquired resistance to PD-1 blockade in melanoma. N Engl J Med 375 : 819-829, 2016

22. Das K, Eisel D, Lenkl C, Goyal A, Diederichs S, Dickes E, Osen W and Eichmüller SB: Generation of murine tumor cell lines deficient in MHC molecule surface expression using the CRISPR/Cas9 system. PLoS One 12: e0174077, 2017.

23. Potter TA, Boyer C, Verhulst AM, Golstein P and Rajan TV: Expression of $\mathrm{H}-2 \mathrm{Db}$ on the cell surface in the absence of detectable beta 2 microglobulin. J Exp Med 160: 317-322, 1984.

24. Allen H, Fraser J, Flyer D, Calvin S and Flavell R: Beta 2-microglobulin is not required for cell surface expression of the murine class I histocompatibility antigen $\mathrm{H}-2 \mathrm{Db}$ or of a truncated $\mathrm{H}-2 \mathrm{Db}$. Proc Natl Acad Sci USA 83: 7447-7451, 1986.

25. Bix M and Raulet D: Functionally conformed free class I heavy chains exist on the surface of beta 2 microglobulin negative cells J Exp Med 176: 829-834, 1992

26. Marozzi A, Meneveri R, Bunone G, De Santis C, Lopalco L, Beretta A, Agresti A, Siccardi AG, Della Valle G and Ginelli E: Expression of $\beta 2 \mathrm{~m}$-free HLA class I heavy chains in neuroblastoma cell lines. Scand J Immunol 37: 661-667, 1993.

27. Kim HS, Garcia J, Exley M, Johnson KW, Balk SP and Blumberg RS: Biochemical characterization of CD1d expression in the absence of beta2-microglobulin. J Biol Chem 274 9289-9295, 1999.

28. Huang WC, Wu D, Xie Z, Zhau HE, Nomura T, Zayzafoon M, Pohl J, Hsieh CL, Weitzmann MN, Farach-Carson MC and Chung LW: Beta2-Microglobulin is a signaling and growth-promoting factor for human prostate cancer bone metastasis. Cancer Res 66: 9108-9116, 2006.
29. Nomura T, Huang WC, Zhau HE, Wu D, Xie Z, Mimata H, Zayzafoon M, Young AN, Marshall FF, Weitzmann MN and Chung LW: Beta2-microglobulin promotes the growth of human renal cell carcinoma through the activation of the protein cinase A, Cyclic AMP-responsive element-binding protein, and vascular endothelial growth factor axis. Clin Cancer Res 12: 7294-7305, 2006.

30. Nomura T, Huang WC, Zhau HE, Josson S, Mimata H and Chung LW: $\beta 2$-Microglobulin-mediated signaling as a target for cancer therapy. Anticancer Agents Med Chem 14: 343-352, 2014.

31. Sneed RA, Stevenson AP and Stewart CC: Quantitation of the host cell infiltration kinetics of the nonimmunogenic colon 26 tumor by multiparameter flow cytometry. J Leukoc Biol 46: 547-555, 1989.

32. Kennedy BC, Maier LM, D'Amico R, Mandigo CE, Fontana EJ, Waziri A, Assanah MC, Canoll P, Anderson RC, Anderson DE and Bruce JN: Dynamics of central and peripheral immunomodulation in a murine glioma model. BMC Immunol 10: 11, 2009.

33. Bindea G, Mlecnik B, Tosolini M, Kirilovsky A, Waldner M, Obenauf AC, Angell H, Fredriksen T, Lafontaine L, Berger A, et al: Spatiotemporal dynamics of intratumoral immune cells reveal the immune landscape in human cancer. Immunity 39: 782-795, 2013.

34. Cheng WF, Hung CF, Lin KY, Ling M, Juang J, He L, Lin CT and Wu TC: CD8 + T cells, NK cells and IFN-gamma are important for control of tumor with downregulated MHC class I expression by DNA vaccination. Gene Ther 10: 1311-1320, 2003.

35. Indrová M, Símová J, Bieblová J, Bubeník J and Reinis M: NK1.1+ cells are important for the development of protective immunity against MHC I-deficient, HPV16-associated tumours. Oncol Rep 25: 281-288, 2011.

36. van der Sluis TC, Sluijter M, van Duikeren S, West BL, Melief CJ, Arens R, van der Burg SH and van Hall T: Therapeutic peptide vaccine-induced CD8 $\mathrm{T}$ cells strongly modulate intratumoral macrophages required for tumor regression. Cancer Immunol Res 3: 1042-1051, 2015.

37. Perea F, Bernal M, Sánchez-Palencia A, Carretero J, Torres C, Bayarri C, Gómez-Morales M, Garrido F and Ruiz-Cabello F: The absence of HLA class I expression in non-small cell lung cancer correlates with the tumor tissue structure and the pattern of T cell infiltration. Int J Cancer 140: 888-899, 2017.

38. Aptsiauri N, Ruiz-Cabello F and Garrido F: The transition from HLA-I positive to HLA-I negative primary tumors: The road to escape from T-cell responses. Curr Opin Immunol 51: 123-132, 2018.

39. Ugurel S, Spassova I, Wohlfarth J, Drusio C, Cherouny A, Melior A, Sucker A, Zimmer L, Ritter C, Schadendorf D and Becker JC: MHC class-I downregulation in PD-1/PD-L1 inhibitor refractory Merkel cell carcinoma and its potential reversal by histone deacetylase inhibition: A case series. Cancer Immunol Immunother 68: 983-990, 2019.

40. Zhang S, Kohli K, Black RG, Yao L, Spadinger SM, He Q, Pillarisetty VG, Cranmer LD, Van Tine BA, Yee C, et al: Systemic interferon- $\gamma$ increases MHC class I expression and T-cell infiltration in cold tumors: Results of a phase 0 clinical trial. Cancer Immunol Res 7: 1237-1243, 2019.

41. Di Vito C, Mikulak J, Zaghi E, Pesce S, Marcenaro E and Mavilio D: NK cells to cure cancer. Semin Immunol 41: 101272, 2019.

42. Wright SE, Rewers-Felkins KA, Chowdhury NI, Ahmed J and Srivastava SK: Prevention of human adenocarcinoma with CpG-ODN in a mouse model. Oncol Lett 4: 1061-1063, 2012.

43. Maimela NR, Liu S and Zhang Y: Fates of CD8+ T cells in tumor microenvironment. Comput Struct Biotechnol J 17: 1-13, 2018. 